\title{
Analisis Faktor-faktor yang Mempengaruhi Struktur Modal Perusahaan Sektor Pertambangan
}

\author{
Noviyanti Nita ${ }^{1}$, Anam Hairul ${ }^{2 *}$ \\ ${ }^{1,2}$ Universitas Balikpapan \\ *hairul@uniba-bpn.ac.id
}

\begin{abstract}
This study aims to determine of profitability, liquidity, assets structure, growth and firm size on the capital structure decision in mining company listed in Indonesian Stock Exchange through the pecking order theory. Pecking order theory prefers internal financing than external financing. The sample used in this study were 11 mining company who listed in Indonesian Stock Exchange. Where the method used was purposive sampling. Analysis of data using multiple regression analysis tools, which is preceded by classical assumption and hypothesis testing used by the $t$ test and $F$ test. Result of regression analysis indicates that simultaneously profitability, liquidity, assets structure, growth and firm size affect the capital structure. While the partially variable affecting significantly is profitability and firm size. While liquidity, assets structure and growth not significantly affect the capital structure.
\end{abstract}

Keyword : pecking order theory, profitability, liquidity, assets structure, growth

\begin{abstract}
Abstrak
Penelitian ini bertujuan untuk mengetahui pengaruh profitabilitas, likuiditas, struktur aset, tingkat pertumbuhan dan ukuran perusahaan terhadap keputusan struktur modal pada perusahaan sektor pertambangan yang terdaftar di Bursa Efek Indonesia melalui teori Pecking Order. Teori Pecking Order lebih mengutamakan pendanaan secara internal daripada pendanaan secara eksternal. Sampel penelitian yang digunakan sebanyak 11 perusahaan sektor pertambangan yang terdaftar di Bursa Efek Indonesia, dimana metode sampling yang digunakan adalah purposive sampling. Analisis data menggunakan alat analisis uji regresi linier berganda yang didahului dengan uji asumsi klasik. Pengujian hipotesis dilakukan dengan menggunakan uji t dan uji F. Hasil uji regresi menunjukkan bahwa secara bersama-sama profitabilitas, likuiditas, struktur aset, tingkat pertumbuhan dan ukuran perusahaan mempunyai pengaruh terhadap struktur modal. Sedangkan secara parsial variabel yang berpengaruh secara signifikan terhadap struktur modal adalah profitabilitas dan ukuran perusahaan. Sedangkan variabel likuiditas, struktur aset dan tingkat pertumbuhan tidak signifikan mempengaruhi struktur modal.
\end{abstract}

Kata kunci : teori pecking order, profitabilitas, likuiditas, struktur aset, tingkat pertumbuhan, dan ukuran perusahaan.

\section{Pendahuluan}

Menghadapi persaingan dalam dunia bisnis dan ekonomi yang semakin keras, membuat perusahaan dihadapkan pada tuntutan agar mempunyai keunggulan dalam persaingan bisnis baik itu dalam teknologi, produk yang dihasilkan maupun sumber daya manusianya. Untuk memilki keunggulan tersebut tentunya perusahaan memerlukan kebutuhan dana yang besar. Untuk menjamin ketersediaan dana tersebut, perusahaan harus mencari sumbersumber permodalan yang dapat menyediakan dana dalam jumlah besar. Setiap perusahaan dituntut untuk bisa membaca dan melihat situasi yang terjadi sehingga mampu mengambil keputusan dalam pengelolaan fungsi-fungsi 
manajemen dengan baik di bidang pemasaran, produksi, sumber daya manusia, dan keuangan dengan baik.

Perusahaan dalam memastikan kegiatan operasionalnya berjalan lancar memerlukan sumber dana yang optimal. Sumber dana berasal dari dua hal yaitu berupa utang dan saham. Sedangkan sumber dana yang kedua berasal dari sumber dana internal yang berupa laba ditahan. Penggunaan utang untuk membiayai kegiatan perusahaan memerlukan pertimbangan risiko agar dapat mencapai struktur modal yang optimal guna memaksimalkan nilai perusahaan. Jika perusahaan mempunyai utang terlalu besar, maka dapat meningkatkan risiko kebangkrutan karena perusahaan harus membayar dana cash flow yang cukup besar untuk membayar cicilan utang beserta bunganya. Utang juga menyebabkan perusahaan rentan terhadap fluktuasi perubahan tingkat suku bunga dan gejolak perubahan nilai uang.

Penggunaan saham pada dasarnya dapat digunakan untuk mencapai tiga tujuan yaitu yang pertama sebagai gudang nilai, berarti investor mengutamakan keamanan investor, yang kedua digunakan untuk penambahan modal yang berarti investor mengutamakan investasi jangka panjang sehingga mereka akan mecari saham pertumbuhan untuk memperoleh capital gain atau saham penghasilan untuk mendapatkan dividen. Dan yang ketiga sebagai sumber penghasilan dimana investor mengandalkan penerimaan dividen.

Kajian tentang pemenuhan sumber pendanaan perusahaan ini dikenal juga dengan teori struktur modal.Ada banyak teori mengenai struktur modal, tetapi dari berbagai teori tersebut masih banyak yang saling bertentangan.Teori struktur modal ini menitikberatkan tentang bagaimana komposisi antara utang jangka panjang dengan saham yang ideal sehingga diperoleh struktur modal yang optimal.Dalam teorinya ada 3 teori yang membahas tentang struktur modal yaitu Trade-off theory, Agency Theory dan Pecking Order Theory.Teori Trade-Off menyatakan bahwa hubungan antara struktur modal dengan nilai perusahaan terdapat suatu tingkat leverage yang optimal.

\subsection{Rumusan Masalah}

Apakah terdapat pengaruh secara simultan maupun parsial dari variabel profitabilitas yang di proksikan dengan Return of Asset, likuiditas yang diproksikan dengan Current Ratio, struktur aset yang diproksikan dengan Tangible Asset, tingkat pertumbuhan yang diproksikan dengan Growth, dan ukuran perusahaanyang diproksikan dengan Size terhadap struktur modal melalui pengujian teori pecking order? 


\section{Landasan Teori, Kajian Empiris dan}

\section{Pengembangan Hipotesis}

\subsection{Struktur Modal}

Struktur modal perusahaan menggambarkan perbandingan antara utang jangka panjang dengan modal sendiri yang digunakan oleh suatu perusahaan.

Lawrence (2000), yaitu modal utang (debt capital) dan modal sendiri (equity capital).Tetapi dalam kaitannya dengan struktur modal, jenis modal utang yang diperhitungkan adalah modal jangka panjang.Sementara modal sendiri adalah dana jangka panjang perusahaan yang disediakan oleh pemilik perusahaan atau pemegang saham yang terdiri dari berbagai jenis saham (saham preferendan saham biasa), serta laba ditahan.Weston dan Copeland (1996) mengatakan bahwa "struktur modal adalah pembiayaan permanen yang terdiri dari utang jangka panjang, saham preferen, dan modal pemegang saham".

\subsection{Teori Pecking Order}

Teori struktur modal yang diperkenalkan oleh Myer pada tahun 1984, menjelaskan bagaimana perusahaan menetapkan struktur modal. Teori pecking order mengasumsikan bahwa perusahaan bertujuan untuk memaksimumkan kesejahteraan pemegang saham. Perusahaan berusaha menerbitkan sekuritas pertama dari internal fund,retained earning, kemudian utang berisiko rendah dan terakhir ekuitas. Dalam teori pecking order , urutan pendanaan akan dimulai dengan: 1 . penggunaan dana internal, 2. penerbitan surat utang, 3. penerbitan saham

Dana internal adalah dana yang sudah tersedia di perusahaan yang diperoleh dari kegiatan yang sudah ada. apabila dana internal tidak mencukupi, maka baru kemudian perusahaan menerbitkan surat utang dan apabila penggunaan utang sudah mencapai batas maksimum, maka langkah terakhir adalah menerbitkan saham.

Myers (1984) dalam Yulinda (2007) menerangkan bahwa perusahaan dalam pemilihan dana akan memilih dana internal terlebih dahulu untuk membayar dividen dan investasi. Jika dana eksternal dibutuhkan, perusahaan lebih memilih utang dibanding sumber dana eksternal lainnya. Brealey (2007) menyatakan bahwa teori pecking order diawali dengan kehadiran informasi yang tidak simetrik. Manajer lebih mengetahui keadaan perusahaan dibandingkan investor. Informasi ini mempengaruhi pilihan antara pembiayan internal dan eksternal.

Wardianto(2013) menjelaskan bahwa teori pecking order lebih menyarankan penggunaan sumber dana internal sebagai sumber pendanaan utama perusahaan. Hubungan antara tingkat laba atau profitabilitas dengan tingkat utang dalam teori pecking order memiliki arah 
profitabilitasnya meningkat, maka tingkat utang perusahaan akan menurun. Sebaliknya, apabila profitabilitasnya menurun maka tingkat utangnya akan meningkat. Christianti (2006) Peneliti menguji variabel-variabel yaitu Tangibility, Size, Growth, Profitability,Earning Volatility dan flexibility, memberikan kesimpulan bahwa Tangibility, Growth dan Profitability mendukung pecking order theory sedangkan earning volatility tidak mendukung static trade-off dan pecking order theory. Hadiyanto (2008) Peneliti menguji 2 sampel perusahaan berdasarkan kriteria sampel yang ditetapkan dengan hipotesa struktur aktiva, ukuran perusahaan, dan profitabilitas berpengaruh negatif terhadap struktur modal. Pengujian hipotesa menggunakan metode analisis verifikatif dengan hasil kesimpulan yang menunjukkan bahwa ukuran perusahaan adalah satu-satunya yang mendukung hipotesis pecking order. Wardianto (2013) Penelitian ini menguji variabel tangibility, pertumbuhan perusahaan, ukuran perusahaan dan profitabilitas sebagai variabel independen dan struktur modal yang diproksikan dengan leverage sebagai variabel dependen dengan menggunakan 10 perusahaan non-bank financial institusin yang selalu listing dalam saham LQ45 di Bursa Efek Indonesia selama periode penelitian tahun 2004 - 2011. Peneliti mengukur Tangibility melalui perbandingan aset tetap dengan total aset.Untuk variabel Growth peneliti mengukur melalui $a$ percentage increase in total assets. Variabel Size diukur melalui logaritma natural total penjualan, sedangkan variabel profitabilitas diukur melalui Return on Assets. Sementara variabel dependen diproksikan dengan leverage. Pengujian hipotesis dilakukan dengan metode regresi linier berganda. Hasil penelitian menunjukkan bahwa tangibility dan profitabilitas terbukti secara parsial berpengaruh signifikan terhadap struktur modal. Dimana profitabilitas mempunyai hubungan negatif terhadap struktur modal sehingga perusahaanperusahaan yang diteliti mendukung konsep pecking order. Sedangkan variabel growthdan size terbukti secara parsial tidak berpengaruh terhadap struktur modal.Yuliati (2011) Penelitian ini menguji variabel-variabel penentu struktur modal seperti Profitabilitas, Likuiditas, struktur aset, Growth, firm size dan risiko bisnis terhadap industry manufaktur di BEI setelah krisis moneter dengan menggunakan 122 perusahaan manufaktur yang terdaftar di Bursa efek Indonesia selama periode penelitian tahun 2006 - 2007. Pengujian hipotesis dilakukan dengan metode regresi linear berganda dengan hasil penelitian yang menunjukkan bahwa profitabilitas dan likuiditas berpengaruh negatif secara signifikan terhadap struktur modal. Sementara ukuran perusahaan berpengaruh 
positif secara signifikan terhadap struktur modal. Sedangkan variabel lainnya seperti struktur aset, kesempatan bertumbuh dan risiko bisnis tidak berpengaruh signifikan terhadap struktur modal.

\section{Hipotesis :}

$\mathbf{H}_{1}$ :Variabel yang diproksikan ke dalam Return of Assets, Current Ratio, Tangible Assets ,Growth dan Size secara simultan berpengaruh terhadap struktur modal pada perusahaan sektor pertambangan melalui teori Pecking Order

$\mathbf{H}_{2}$ :Variabel Profitabilitas, Likuiditas, Struktur aktiva, Tingkat pertumbuhan dan Ukuran Perusahaan secara parsial berpengaruh terhadap struktur modal pada perusahaan sektor pertambangan melalui teori Pecking Order

\section{Metode Penelitian}

\section{Data Penelitian}

Pada penelitian ini, penulis memperoleh data sekunder berdasarkan : Pusat Referensi Pasar Saham (PRPM) seperti Indonesian Capital Market Directory tahun 2008 - 2012, laporan tahunan perusahaan (Annual Report), www.idx.co.id. Dan www.sahamok.com

\section{Populasi dan Sampel}

Perusahaansektor pertambangan dipilih karena merupakan lahan yang strategis untuk mendapatkan keuntungan dalam berinvestasi.
Teknik sampling yang digunakan pada penelitian ini adalah metode purposive sampling, dengan metode ini penulis melakukan pemilihan sampel sesuai dengan keperluan data dan informasi yang dibutuhkan.Terdapat 38 perusahaan, berdasarkan karakteristik penarikan sampel, maka diperoleh sampel penelitian sebanyak 13 perusahaan sektor pertambangan selama periode penelitian.Dari hasil penarikan sampel tersebut, diperoleh sebanyak 11 perusahaan sampel yang memenuhi kriteria yang telah ditentukan.

\subsection{Alat Analisis dan Pengujian Hipotesis}

\section{Analisis Regresi Linier Berganda}

Penelitian ini menggunakan analisis regresi linier berganda untuk mengetahui pengaruh variabel profitabilitas, likuiditas, struktur aktiva, dan ukuran perusahaan terhadap struktur modal yang di proksikan dengan debt to equity ratio.

Persamaan yang digunakan dalam penelitian ini yaitu :

$\mathrm{Y}=\alpha+\mathrm{b}_{1} \mathrm{X}_{1}+\mathrm{b}_{2} \mathrm{X}_{2}+\mathrm{b}_{3} \mathrm{X}_{3}+\mathrm{b}_{4} \mathrm{X}_{4}+\mathrm{b}_{5} \mathrm{X}_{5}+\mathrm{e}$

Dimana :

$\mathrm{Y}=$ Tingkat Utang( Leverage Ratio $)$

$\mathrm{A}=$ Konstanta

$\mathrm{b}_{1}, \mathrm{~b}_{2}, \mathrm{~b}_{3}, \mathrm{~b}_{4}, \mathrm{~b}_{5}, \mathrm{~b}_{5}=$ Koefisien perubahan nilai

$\mathrm{X}_{1}=$ Profitabilitas $(\mathrm{ROA})$

$\mathrm{X}_{2}=$ Likuiditas

$\mathrm{X}_{3}=$ Struktur Aktiva

$\mathrm{X}_{4}=$ Tingkat Pertumbuhan 
$\mathrm{X}_{5}=$ Ukuran Perusahaan

\subsection{Pengujian Asumsi Klasik}

Pengujian klasik untuk mengetahui apakah model regresi benar-benar menunjukkan hubungan yang signifikan dan representative dan pengujian asumsi klasik dalam penelitian ini meliputi : Uji Normalitas,

Autokorelasi,

Heterokedastisitas, Multikolinearitas

Uji Koefisien Determinasi $\left(\mathbf{R}_{2}\right)$

Koefisien Determinasi $\left(\mathrm{R}_{2}\right)$ berguna untuk mengukur sebagian besar peranan variabel independen atau bebas terhadap variabel dependen terikat.

\section{Pengujian Hipotesis}

\section{Uji Hipotesis Secara Parsial (Uji t)}

Suliyanto (2011:62) suatu variabel memiliki pengaruh jika nilai $t_{\text {hitung }}$ variabel lebih besar dibandingkan nilai $t_{\text {tabel. }} . \mathrm{Uji}$ hipotesis secara parsial dilakukan dengan uji t. Uji t ini digunakan untuk menunjukkan seberapa jauh pengaruh satu variabel independen secara individual dalam menerangkan variabel dependen.

\section{Uji F (Goodness of Fit Model)}

Suliyanto (2011) uji F atau yang sering disebut sebagai uji simultan bertujuan untuk menguji apakah variabel independen yang digunakan dalam model mampu menjelaskan perubahan nilai variabel tergantung atau tidak. Untuk mengetahui apakah model masuk dalam kategori cocok (fit) atau tidak, harus membandingkan nilai $F_{\text {hitung }}$ dengan nilai $F_{\text {tabel }}$ dengan derajat bebas.

\section{Hasil Dan Pembahasan}

\subsection{Deskripsi Variabel Penelitian}

Uji Asumsi Klasik

a. Uji Normalitas

Hasil uji normalitas pada 55 data sampel menunjukkan bahwa hanya dua variabel yaitu ROA (Return of asset) dan GROW (Growth) yang berdistribusi normal dengan signifikansi diatas 0,05. Hal ini ditunjukkan dengan nilai signifikansi pengujian One-sample Kolgomorovsmirnov test diatas 0,05 .

b. Uji Autokorelasi

Hasil uji autokorelasi, diperoleh hasil Durbin-Watson sebesar 1,784 dari 55 data sampel dengan variabel berjumlah $5(\mathrm{n}=$ $55, \mathrm{k}=5)$ sehingga nilai lower bound $(\mathrm{dl})=$ 1,374 , nilai batas atas $(\mathrm{du})=1,768$, nilai 4 $\mathrm{du}=2,232$ dan nilai $4-\mathrm{dl}=2,626$. Dengan demikian nilai Durbin-Watson berada diantara du dan 4-du sehingga dapat disimpulkan bahwa hasil regresi tidak terdapat autokorelasi.

c. Uji Heterokedastisitas

Untuk mendeteksi ada atau tidaknya heterokedastisitas dapat digunakan metode grafik, yaitu dengan menghubungkan nilai variabel dependen yang diprediksi dengan nilai residualnya (Y prediksi $-\mathrm{Y}$ sesungguhnya) dimana sumbu $\mathrm{X}$ adalah nilai variabel dependen yang diprediksi dan sumbu Y adalah residualnya.Jika titik-titik 
dalam grafik membentuk suatu pola tertentu maka data terindikasi heterokedastisitas. Tetapi jika titik-titik dalam grafik menyebar diatas dan dibawah angka 0 pada sumbu Y, maka tidak terjadi heterokedastisitas. Data tidak terjadi heterokedastisitas karena titiktitik dalam grafik menyebar dan tidak membentuk pola tertentu.

\section{d. Uji Multikolinearitas}

Uji ini dapat dilihat dengan nilai Tolerance dan Variance Inflation Factor (VIF).Tolerance mengukur variabel bebas lainnya. Jadi nilai tolerance yang rendah sama dengan nilai variance inflation factor tinggi (Karena nilai variance inflation factor $=1 /$ tolerance $)$ dan menunjukkan adanya kolinearitas yang tinggi. Nilai cut off yang umum dipakai adalah nilai tolerance 0.10 atau nilai variance inflation factor yang berada dibawah nilai $10 \%$. Jadi multikolinearitas terjadi jika nilai tolerance $<0.10$ atau nilaivariance inflation factor $>$ $10 \%$. Hasil pengolahan data nilai variance inflation factor.

\section{Uji Parsial (Uji t)}

Pengujian ini dilakukan untuk mengetahui seberapa jauh pengaruh variabel yaitu Return of Assets (Profitabilitas), Current Ratio (Likuiditas), Tangibility (Struktur Aset), Growth (Tingkat pertumbuhan), dan Size (Ukuran Perusahaan) terhadap yaitu Debt to Equity Ratiomelalui Teori Pecking Order. Pengujian ini dilakukan dengan membandingkan signifikansi $t_{\text {hitung }}$ masingmasing variabel.

Hasil pengujian persamaan regresi sebagai berikut :

$\mathrm{DER}=807,423-5,2947 \mathrm{X}_{1}-0.113 \mathrm{X}_{2}-0,870 \mathrm{X}_{3}+0,650 \mathrm{X}_{4}-20,155 \mathrm{X}_{5}$

Analisa Persamaan regresi diatas adalah sebagai berikut :

1) Konstanta sebesar 807,423 , artinya jika Profitabilitas $\left(\mathrm{X}_{1}\right)$, Likuiditas $\left(\mathrm{X}_{2}\right)$, Struktur Aset $\left(\mathrm{X}_{3}\right)$, Tingkat Pertumbuhan $\left(\mathrm{X}_{4}\right)$, dan Ukuran Perusahaan $\left(\mathrm{X}_{5}\right)$ nilainya adalah 0 , maka Struktur modal yang diproksikan dengan tingkat utang (Y) nilainya akan meningkat sebesar 807,423 persen.

2) Variabel Profitabilitas $\left(X_{1}\right)$

Berdasarkan hasil penelitian didapatkan nilai koefisien variabel Profitabilitas yang diukur melalui
Return of Asset sebesar -5,294. Dari perhitungan uji secara parsial diperoleh $t_{\text {hitung }}$ sebesar-4,539 dan nilai signifikansi sebesar $0,00 . \quad$ Nilai signifikansi yang lebih kecil dari 0,05 menunjukkan bahwa variabel Profitabilitasmemiliki pengaruh yang signifikan terhadapStruktur Modal yang diproksikan sebagai Debt to Equity. Dengan demikian Hipotesis 2 diterima. Hasil uji hipotesis yang menunjukkan angka signifikan dengan arah koefisien regresi bertanda negatif menunjukkan bahwa semakin tinggi 
profitabilitas perusahaan maka tingkat utang perusahaan akan semakin kecil dan begitu pula sebaliknya. Koefisien regresi sebesar -5,294 menunjukkan apabila profitabilitas mengalami peningkatan 1 persen maka tingkat utang akan menurun sebesar 5,294 persen dengan asumsi variabel lainnya konstan.

3) Variabel Likuiditas $\left(X_{2}\right)$

Berdasarkan hasil persamaan regresi linier berganda nilai koefisien Current Ratio sebesar 0,113 dengan arah negatif. Sedangkan hasil uji secara parsial menunjukkan nilai $t_{\text {hitung }}$ sebesar -1,940 dengan nilai signifikan sebesar 0,058. Karena nilai signifikan lebih besar dari 0,05 menunjukkan bahwa variabel Likuiditas mempunyai pengaruh yang tidak signifikan terhadap struktur modal. Dengan demikian hipotesis 2 tidak diterima. Koefesien regresi sebesar -0,113 menunjukkan bahwa jika likuiditas meningkat sebesar 1 persen maka tingkat utang akan menurun sebesar 0,113 persen dengan asumsi variabel lainnya konstan.

4) Variabel Struktur Aset $\left(X_{3}\right)$

Hasil dari persamaan regresi linier berganda menunjukkan nilai koefisien Tangibility (Struktur Aset) sebesar 0,870. Hasil uji secara parsial menunjukkan nilai $t_{\text {hitung }}$ sebesar $-1,654$ dengan nilai signifikan sebesar 0,105. Nilai signifikan yang lebih besar dari 0,05 maka variabel Struktur Aset terbukti tidak berpengaruh secara signifikan terhadap Debt to Equity (Struktur Modal). Koefisien regresi sebesar -0,870 menunjukkan bahwa jika Struktur Aset mengalami peningkatan 1 persen maka tingkat utang akan menurun sebesar 0,870 persen dengan asumsi variabel lainnya konstan. Struktur Aset berpengaruh tidak signifikan berarti pada perusahaan Sektor pertambangan perubahan tingkat utang tidak dipengaruhi oleh nilai struktur aset.

5) Variabel Tingkat Pertumbuhan $\left(X_{4}\right)$

Hasil persamaan regresi linier menunjukkan nilai koefisiean Growth (Tingkat Pertumbuhan) sebesar 0,650 dengan arah positif. Hasil uji parsial menunjukkan nilai $t_{\text {hitung }}$ sebesar 1,470 dan nilai signifikan 0,148

Karena nilai signifikan lebih besar dari 0,05 maka variabel Growth (tingkat pertumbuhan) berpengaruh secara tidak signifikan terhadap Debt to Equity. Koefisien regresi sebesar 0,650 menunjukkan bahwa jika variabel tingkat pertumbuhan meningkat 1 persen maka tingkat utang juga akan meningkat sebesar 0,650 persen 
dengan asumsi variabel lainnya konstan.

6) Variabel Ukuran Perusahaan $\left(X_{5}\right)$

Hasil persamaan regresi linier menunjukkan nilai koefisien variabel Size (Ukuran Perusahaan) sebesar 20,15. Sedangkan hasil uji parsial menunjukkan hasil $t_{\text {hitung }}$ sebesar $-2,757$ dengan nilai signifikan sebesar 0,008 Nilai signifikan variabel Size yang lebih kecil dari 0,05 menunjukkan bahwa variabel Size (ukuran perusahaan) terbukti berpengaruh negatif secara signifikan terhadap Debt to Equity, maka hipotesis yang menyatakan bahwa ukuran perusahaan berpengaruh secara signifikan dapat diterima. Koefisien regresi sebesar 20,15 menunjukkan jika Ukuran perusahaan meningkat 1 persen maka tingkat utang akan menurun 20,15 persen dengan asumsi variabel lainnya konstan.

\section{Uji Simultan}

Uji F (Uji Simultan) dilakukan untuk melihat apakah secara keseluruhan variabel bebas mempunyai pengaruh terhadap variabel terikat.

Nilai F untuk data sampel diperoleh sebesar 11,363 dengan nilai signifikansi lebih kecil dari 0,05. Dengan menggunakan taraf signifikansi 5\% maka dapat disimpulkan bahwa koefisien regresi tidak sama dengan nol. Karena nilai signifikansi yang kurang dari 5\%, maka dapat disimpulkan terdapat pengaruh secara bersama-sama kelima variabel independen terhadap variabel dependen. Dengan demikian $\mathrm{H}_{1}$ tidak ditolak atau diterima.

\section{Koefisien Determinasi $\left(\mathbf{R}^{2}\right)$}

Hasil analisis menunjukkan nilai adjusted $R^{2}$ sebesar 0,490 berarti bahwa sebesar $49 \%$ Debt to Equity dapat diprediksi oleh variasi Return of Assets, Current Ratio, Tangibility, Growth dan Size. Dan sebesar $51 \%$ variabel Debt to Equity dijelaskan oleh faktor lainnya.

\section{Koefisien Parsial}

Untuk mengetahui besarnya kontribusi masing-masing variabel bebas terhadap variabel terikat dengan mempertimbangkan hubungan variabel bebas lainnya, baik terhadap variabel bebas yang dicari kontribusinya, diperlukan analisis tersendiri. Apabila yang dihadapi adalah regresi dengan dua atau lebih variabel bebas, maka akan diperoleh korelasi parsial sebanyak jumlah variabel bebas.

Korelasi parsial antara Profitabilitas yang diukur melalui Return of Assets dengan Struktur Modal yang diproksikan melalui Debt to Equity Ratio diperoleh sebesar koefisien korelasi parsial $(\mathrm{r})=$ 0,544 yang menunjukkan hubungan antara variabel Profitabilitas terhadap Struktur Modal memiliki hubungan negatif dan 
kontribusi pengaruhnya sebesar

Determinasi Parsial $r^{2}(r$ Square $)=-0,441$ atau $-44,1 \%$.

Korelasi parsial antara Likuiditas yang diukur dengan Current Ratio dengan Struktur Modal yang diproksikan melalui Debt to Equity Ratio diperoleh sebesar koefisien korelasi parsial $(r)=-0,267$ yang menunjukkan hubungan negatif antara variabel Likuiditas terhadap Struktur Modal dan kontribusi pengaruhnya sebesar Determinasi Parsial $r^{2}$ (r Square) $=-0,189$ atau $-18,9 \%$.

Korelasi parsial antara Struktur Aset yang diukur melalui Tangibility dengan Struktur Modal Modal yang diproksikan melalui Debt to Equity Ratio diperoleh sebesar koefisien korelasi parsial (r) = 0,230 yang menunjukkan hubungan negatif antara variabel Struktur Aset terhadap Struktur Modal dan kontribusi pengaruhnya sebesar Determinasi Parsial $r^{2}$ $(\mathrm{r}$ Square $)=-0,161$ atau $-16,1 \%$.

Korelasi parsial antara Tingkat Pertumbuhan yang diukur melalui Growth dengan Struktur Modal Modal yang diproksikan melalui Debt to Equity Ratio diperoleh sebesar koefisien korelasi parsial (r) = 0,206 yang menunjukkan hubungan positif antara variabel Tingkat Pertumbuhan terhadap Struktur Modal dan kontribusi pengaruhnya sebesar Determinasi Parsial $r^{2}$ (r Square $)=0,143$ atau $14,3 \%$.
Korelasi parsial antara Ukuran Perusahaan yang diukur melalui Size dengan Struktur Modal Modal yang diproksikan melalui Debt to Equity Ratio diperoleh sebesar koefisien korelasi parsial (r) = -0,366 dan kontribusi pengaruhnya sebesar Determinasi Parsial $r^{2}(r$ Square $)=$ $-0,268$ atau $-26,8 \%$.

\subsection{Pembahasan}

1. Pengaruh Profitabilitas terhadap

Struktur Modal

Berdasarkan hasil penelitian diperoleh bahwa profitabilitas mempunyai pengaruh negatif signifikan terhadap struktur modal. Tingkat pengembalian keuntungan yang tinggi atas investasi menyebabkan penggunaan utang yang relatif kecil. Tingkat pengembalian yang tinggi juga memungkinkan untuk membiayai sebagian besar kebutuhan pendanaan yang dihasilkan secara internal. Hasil penelitian ini sejalan dengan penelitian Sri Yuliati (2011), Wardianto (2013) dan Bram Hadiyanto (2008) yang menunjukkan bahwa profitabilitas mempunyai pengaruh secara terhadap struktur modal.

2. Pengaruh Likuiditas terhadap Struktur Modal

Berdasarkan hasil penelitian diperoleh hasil yang menunjukkan bahwa likuiditas mempunyai pengaruh negatif tidak signifikan terhadap struktur modal. Likuiditas mempunyai pengaruh negatif 
terhadap struktur modal menunjukkan bahwa hubungan antara kemampuan perusahaan dalam melunasi utangnya dengan menggunakan aktiva lancar yang dimiliki terhadap struktur modal bertolak belakang. Variabel likuiditas yang tidak signifikan mungkin disebabkan karena perusahaan-perusahaan di sektor pertambangan pada tahun 2008 hingga 2012 memiliki likuiditas terbaik, sehingga tidak ada keraguan tentang kemampuan perusahaan melunasi utang lancarnya.Hasil penelitian ini tidak sejalan penelitian Sri Yuliati (2011) yang menunjukkan hasil Likuiditas berpengaruh signifikan dengan koefisien regresi sebesar -2,24 yang berarti semakin besar likuiditas perusahaan maka akan semakin kecil penggunaan utang dikarenakan kemampuan perusahaan untuk membayar utangnya.

3. Pengaruh Struktur Aset terhadap Struktur Modal

Berdasarkan hasil penelitian diperoleh hasil yang menunjukkan bahwa struktur aset mempunyai pengaruh negatif tidak signifikan terhadap struktur modal. Pengaruh negatif tersebut menunjukkan jika struktur aset perusahaan semakin meningkat, maka akan menurunkan penggunaan utang pada perusahaan tersebut.Hasil ini sejalan penelitian Sri Yuliati (2011) yang menunjukkan hasil bahwa Tangibility (Struktur Aset) mempunyai pengaruh negatif tidak signifikan terhadap struktur modal. Namun hasil penelitian ini tidak sejalan hasil penelitian K. Bagus Wardianto (2013) yang menunjukkan hasil variabel Tangibility (struktur aset) mempunyai pengaruh signifikan terhadap struktur modal.

4. Pengaruh Tingkat Pertumbuhan terhadap Struktur Modal

Berdasarkan hasil penelitian diperoleh hasil yang menunjukkan bahwa tingkat pertumbuhan mempunyai pengaruh positif tidak signifikan terhadap struktur modal. Hal ini berarti bahwa jika tingkat pertumbuhan perusahaan yaitu pertumbuhan aset meningkat, maka proporsi penggunaan utang juga akan meningkat.Hasil ini sejalan penelitian $\mathrm{K}$. Bagus Wardianto (2013) yang menunjukkan hasil bahwa variabel Growth terbukti tidak berpengaruh secara parsial terhadap struktur modal yang diproksikan sebagai Debt to Equity.Hasil penelitian ini juga sejalan penelitian Sri Yuliati (2011) yang menunjukkan bahwa variabel tingkat pertumbuhan tidak berpengaruh secara signifikan terhadap struktur modal.

5. Pengaruh Ukuran Perusahaan Terhadap struktur Modal

Berdasarkan hasil penelitian diperoleh hasil yang menunjukkan bahwa ukuran perusahaan mempunyai pengaruh negatif secara signifikan terhadap struktur modal. Ketika ukuran suatu perusahaan 
semakin besar artinya perusahaan tersebut lebih banyak membutuhkan dana eksternal. Hal tersebut dikarenakan perusahaan besar memiliki kebutuhan dana yang besar dan salah satu alternatif pendanaan adalah dengan menggunakan dana eksternal. Namun, semakin besarnya ukuran suatu perusahaan yang ditandai dengan meningkatnya aset, maka menunjukkan bahwa besarnya ukuran perusahaan tersebut dapat membuat perusahaan mengurangi jumlah utangnya, karena perusahaan lebih mengutamakan sumber dana internalnya daripada dana eksternal. Hal tersebut konsisten dengan teori Pecking Order yang menjelaskan bahwa perusahaan lebih menyukai pendanaan internal daripada eksternal, sejalan dengan penelitian Bram Hadianto (2008) yang menunjukkan hasil bahwa variabel Size berpengaruh negatif secara signifikan terhadap struktur modal.

\section{Kesimpulan.}

Dari hasil analisis data didaptkan bahwa Profitabilitas, Likuiditas, Struktur Aset, Tingkat Pertumbuhan dan Ukuran Perusahaan secara bersama-sama (simultan) berpengaruh terhadap struktur modal.

Hasil uji hipotesis secara parsial menunjukkan bahwa :

a. Profitabilitas mempunyai pengaruh negatif signifikan terhadap struktur modal pada perusahaan sektor pertambangan. Hal ini sesuai dengan teori Pecking Order yang menyatakan bahwa apabila profitabilitas semakin tinggi maka akan meningkatkan sumber dana internal sehingga penggunaan utang semakin rendah.

b. Likuiditas mempunyai pengaruh negatif tidak signifikan terhadap Struktur Modal pada perusahaan sektor pertambangan. Semakin besar likuiditas perusahaan maka akan semakin kecil penggunaan utang karena adanya kemampuan perusahaan untuk membayar utangnya melalui sumber dana internal. Hal ini mendukung teori Pecking Order.

c. Struktur Aset mempunyai pengaruh negatif tidak signifikan terhadap Struktur Modal pada perusahaan sektor pertambangan

d. Tingkat pertumbuhan mempunyai pengaruh positif tidak signifikan terhadap Struktur Modal pada perusahaan sektor pertambangan

e. Ukuran Perusahaan mempunyai pengaruh negatif signifikan terhadap struktur modal pada perusahaan sektor pertambangan. Hal ini sesuai dengan teori Pecking Order.

Hasil penelitian menunjukkan bahwa dalam pengambilan kebijakan pendanaan (utang) maka perusahaan yang menjadi sampel telah melakukan kombinasi dari 
dana eksternal dan internal (Teori Pecking

Order). Apabila sumber dari dana internal tidak mencukupi maka dengan mempertimbangkan ukuran perusahaan masih memungkinkan perusahaan untuk memenuhi sebagian kebutuhan pendanaannya melalui penggunaan utang.

\section{Daftar Pustaka}

Brigham, Eugene dan Joel F Houston.2011. Manajemen Keuangan, Jilid 2, Edisi 11. Jakarta : Salemba Empat.

Brealey, Richard A , Stewart C. Myers, dan Alan J. Marcus. 2007. Dasar-Dasar Manajemen Keuangan Perusahaan. Jilid 2. Edisi Kelima. Jakarta: Erlangga

Christianti, Ari. 2006. Penentuan Perilaku Kebijakan Struktur Modal Pada Perusahaan Manufaktur Di Bursa Efek Jakarta : Hipotesis Static Trade Off Atau Pecking Order Theory. Simposium Nasional Akuntansi 9 Padang

Hadianto, Bram. 2008. Pengaruh Struktur Aktiva, Ukuran Perusahaan, Dan Profitabilitas Terhadap Struktur Modal Emiten Sektor Telekomunikasi Periode 2000 - 2006 : Sebuah Pengujian Hipotesis Pecking Order. Jurnal Manajemen, Vol.7 No.2

Hanafi, M.Mamduh dan Abdul, Halim. 2004. Manajemen Keuangan. Yogyakarta: PT. BPFE

Hartono, Jogiyanto. 2011. Teori Portofolio dan Analisis Investasi.Edisi 7. Yogyakarta: PT. BPFE

Jensen, Michael.C dan William H. Meckling. 1976. Theory of The Firm : Managerial Behavior, Agency Cost and Ownership Structure. Journal of Financial Economics. Vol. 3. No.4. pp. $305-360$

Lawrence, Gitman. 2000. Principle of Managerial Finance, Edisi 9. AddisonWeasley

Rachmawardani, Yulinda. 2007. Analisis Pengaruh Aspek Likuiditas, Risiko Bisnis, Profitabilitas, Dan Pertumbuhan Penjualan Terhadap Struktur Modal Perusahaan (Studi Empiris Pada Sektor Keuangan dan Perbankan di BEJ Tahun
2000-2005). Tesis. Program Studi Magister Manajemen Program Pascasarjana Universitas Diponegoro

Riyanto, Bambang. 2008. Dasar-Dasar Pembelanjaan Perusahaan, Edisi Keempat, Cetakan Ketujuh.Yogyakarta : PT. BPFE

Santoso, Singgih. 2012. Aplikasi SPSS Pada Statistik Parametrik. Jakarta : PT. Elex Media Komputindo

Sartono, Agus. 2008. Manajemen Keuangan Teori, dan Aplikasi. Yogyakarta : PT. BPFE

Sugiyono. 2010. Metode Penelitian Kuantitatif Kualitatif Dan R\&D. Bandung : Alfabet, Bandung

-----------, 2014, Metode Penelitian Manajemen, Cetakan ke dua, Alfabet, Bandung

Suliyanto. 2011. Ekonometrika Terapan : Teori Dan Aplikasi Dengan SPSS. Yogyakarta : Andi

Sutrisno. 2005. Manajemen Keuangan Teori, Konsep, dan Aplikasi. Yogyakarta : Ekonisi

Yuliati,Sri. 2011. Pengujian Pecking Order Theory : Analisis Faktor-Faktor Yang Mempengaruhi Struktur Modal Industri Manufaktur Di BEI Periode Setelah Krisis Moneter. Jurnal Politeknosains Vol.X No.1

Wardianto, K Bagus,2013. "Pengujian Pecking Order Theory Pada Non-Bank Financial Institution (NBFIs) Di Indonesia". Jurnal Perspektif Bisnis, Vol.1, Juni 2013

Weston, J.Fred dan Thomas E. Copeland. 1996. Manajemen Keuangan. Edisi 8.Jilid 2.Jakarta : Erlangga 